\title{
Industrial Training Programmes of Polytechnics in Ghana: The Pertinent Issues
}

\author{
Kwabena Nduro ${ }^{1, *}$, Isaac Kofi Anderson ${ }^{2}$, James Adu Peprah ${ }^{3}$ \& Frank B.K. Twenefour ${ }^{4}$ \\ ${ }^{1}$ Graphics Department, Takoradi Polytechnic, Takoradi, Ghana \\ ${ }^{2}$ Industrial Liaison Office, Takoradi Polytechnic, Takoradi, Ghana \\ ${ }^{3}$ Purchasing and Supply Department, Takoradi Polytechnic, Takoradi, Ghana \\ ${ }^{4}$ Department of Statistics, Takoradi Polytechnic, Takoradi, Ghana \\ *Corresponding author: Graphics Department, Takoradi Polytechnic, Takoradi, Ghana. E-mail: \\ highpriest31@gmail.com
}

Received: December 6, 2014

Accepted: January 9, $2015 \quad$ Online Published: February 2, 2015

doi:10.5430/wje.v5n1p102

URL: http://dx.doi.org/10.5430/wje.v5n1p102

\begin{abstract}
In today's world of stiff competition in the labour market, coupled with advanced technology, industries require of students to have job experience before employing them. The challenge here is that the experience being required is not taught in the lecture rooms. The reality is that, it is only gained though hands on the job, thus real world confrontation popularly called industrial attachment a platform for students arm themselves with all the skill, knowledge and demanded experience. This article examines the industrial attachment programmes of polytechnics in Ghana and pertinent issues involved. The paper tackled the problem from four thematic areas; the preparation before the training starts, the perceived challenges encountered, the benefits derived from embarking on the training and suggested strategies to be employed to enhance the programme.
\end{abstract}

Keywords: Takoradi Polytechnic; industrial training; internship; education; industrial liaison office and unemployment

\section{Introduction}

The debate on improving higher education in the world over, Africa, and for that matter Ghana still lingers on. The focus used to be on access, but recently, has assumed a new dimension, thus the ill preparation of graduates or products for the job market. Employees according to Kagaari (2007) are not highly enthused about the quality of skills of graduates or products churned out by our higher educational institutions(HEIs) onto the labour market. This he placed the blame squarely on the doorstep of the academic institutions, and the nature of programmes they run for their students, which one may not be far from right to say, does not lends itself so easily to the ever changing environment, and practices of industry (Jamali, 2005). Blom and Saeke (2011), supporting the argument believes the challenge is due to the insufficient supply of quality skills, and is posing major problems for industries of today. Effah, Boampong, Adu, Anokye and Asamoah (2014) in a related study, and doing a comparative analysis pointed out that, most developed countries have achieved this feat as a result of establishing institutions with the sole aim of giving its products technical and technological training. The object according to them is to take care of unemployment and human resource challenges by churning out products with the required quality skills to enhance productivity and development of their nations' economy.

Most developing countries in Africa especially Ghana has undergone several educational reforms. According to Effah et al. (2014) citing the Ghana News Agency (GNA) (2013), not less than 12 educational reforms with emphasis on basic education. Polytechnics in Ghana, started as Technical, and Training Institutes, and were elevated to tertiary level by the PNDC Law 321, Act 745 of 2007, in recognition of their achievements. The object for establishing Polytechnic Education is to promote technical, vocational education and training, technology transfer and skills development to enhance the socio- economic development of the country. Amaniampong (2014) added polytechnic education plays a key role in human resource development of a country creating skilled manpower, 
enhancing industrial productivity and improving the quality of life. Technical education he said covers courses and programmes in engineering, draughtsmanship, town planning technology, management, applied arts and crafts, hotel and catering management. Dagyenga (2013) emphasised, the polytechnics also has the mandate to run other programmes as it may be deem fit and valuable by the polytechnic authorities and encourage study in technical subjects at the tertiary level.

The idea of establishing polytechnics was to give the sole responsibility of training people with quality entrepreneurial skills to curtail the unemployment situation in the country, and as well enhance productivity and development as earlier emphasised. The deliberations so far points to the fact that the polytechnics in Ghana were established on the firm foundations of practical based learning and training, offering wide options in diverse disciplines. In this regard, Effah et al. (2014) emphasised that, the essence of polytechnic education "is to make an engineer out of the engineering student, an accountant out of the accounting student, designer out of the graphic art student, and not merely to school them through the principles and theories of their various programmes".

In a simple comparative analysis of the polytechnic student, and others in terms of practical based work, Dagyenga(2013) was so explicit in his argument, noting that polytechnic products stand tall when it comes to practical works, and exhibit high level of intelligence and problem solving skills. Expatiating further, minced no words in saying even when they find themselves in institutions of advanced learning in their chosen disciplines; polytechnic students always have the upper hand, and the competitive urge due to their practical based experience. He also showered praises on them in terms of innovation and improving the lot of the citizenry. He cited the fufu pounding machine and the solar wheel chair as some of the inventions between Kumasi and Koforidua polytechnics.

Successive governments in Ghana have always made it a core part of their plans to develop the country and ensure educational institutions churn out quality, educated, skilled and informed products, who have the urge to put into practice, the knowledge, wisdom and quality skills acquired during their period of learning, and to turn around the key areas of the economy to ensure wealth creation and poverty reduction among its citizenry (Effah et al. 2014). This brings in the issue of high unemployment, which is become a global phenomenon, and seems to be prevalent in third world countries (Emeka, 2011). The phenomenon used to be general, but currently, the shift is on graduate employment. Current debate puts emphasis on employability skills which seek to create the impression that graduates come to the work place not fully armed with all the quality skills, and training to deliver (Sheldon \& Thornwaite, 2005).

Adding to it, Bennett (2002) indicated the production and manufacturing industry seek after a population that is flexible, adaptable to changing trends. On the part of Cox and King (2006) this prior expectation of employers does not mean fresh employed graduates should hit the ground running immediately upon appointment without further cushioning, rather need to arm themselves with the needed skills that enhance employment opportunities ( Kagaari, 2007; Maher and Graves, 2008). In this regard, Harvey (2004) concluded, having the right mix of knowledge, skills and abilities makes fresh graduates marketable and successful in their chosen disciplines either in paid or unpaid employment. On their part Nevett (1986) and Pianko (1996) pointed out that trainees, if employed require less training and less time adjusting, than do non- trainees and as well learn quickly, and represent flexible economic resources. Scholars in literature have earlier emphasised on industrial training or attachment as one of the formidable and effective means of developing the raw skills and talents of graduates and eventually address the unemployment situation in the country.

Defining the concept Fox (2001) and Neuman (1999) said industrial practical training is considered an opportunity to close the gap between school learned theory and practical reality. He went on to add that it creates the platform to test skills, interests, and career choices in real working situations while obtaining an edge on inexperienced job market competitors. Collins (2001) on his part said "internship is a "bridge" from classroom to workplace. Touching on students attitude towards the training Higham and Seymore II(1996) noted for some students, it is a requirement to be met in order to graduate, whiles others sees industrial training as platform to get connected, explore new fields of knowledge and acquire experience. From the perspective of the industry, industrial training is a "golden opportunity to try, test before buying" students they might wish to recruit after graduation (Neuman, 1999; Cates-McIver, 1999).

In the nutshell industrial training is seen as a short term practical work experience in which students train and gain experience in a specific field or career area of their interests. It is worth noting for their contributions, interns may or may not be paid anything depending on the situation.

The object of industrial training in the view of Ab Rahman, Omar, Kofli, Mat, Osman and Darus (2009) "is to expose student trainees to the whims and caprices of the working environment (industry). Maher and Graves (2008), 
touching on the importance of industrial training noted that students who embark on industrial training or attachment develop much and greater confidence, and always very much at ease when absorbed into real working life situations, concluding that it is not surprising the industrial training is mandatory for students and very much encouraged in polytechnic curriculum. On the part of Shipton et al. (2006) as part of the benefits derived from industrial training noted that it helps graduates to manage what he termed as "entry shock" when they find themselves on the job market. From the industrial perspective some firms cannot function without trainees as they may not have the money to recruit workers, and have to fall on interns, this Miner and Crane(1995) pointed out, it is viewed by many firms as very inexpensive labor to tap.

The addition of the industrial training in the polytechnic's curriculum is purposely to attach trainees to course related industries and the environment in which they operate, give them hands on practicals in their various fields, transfer knowledge acquired in the lecture hall to real world- of -work, familiarize themselves with new technological trends, and have the opportunity to bridge the gap that exists between theory and practice. As earlier talked about the unemployment situation of polytechnic graduates is worrying, raising shades of concerns, and headache to government, thus implementing initiatives and programmes like the National Youth Employment Programme (NYEP) by the erstwhile President Kufour administration, and the Ghana Youth in Employment and Entrepreneurial Development Agencies (GYEEDA) by the current government, to offer graduates the needed market skills to fit into industry after school. In this regard Polytechnics in Ghana were directed by government to structure their programmes to introduce innovative ideas and inventions, develop critical manpower capable of meeting the current expectations of businesses and the economy at large (Ghana MOESS, 2008).

Effah et al (2014) in a related study looking at the issue from three thematic areas thus; evidence of early preparation, challenges of industrial attachment programme and strategies for effective attachment programme discovered students are served with or issued attachment letters early which creates an equal platform for them to compete with trainees from the university and other tertiary institutions, they also professed being well oriented ahead of time for industrial training. The ILO according to results of the survey shows the office wastes no time in telling students of any opening anywhere for placement. In addition any information relating to industrial attachment is put at their door step for access. On the other hand, the results revealed that matters relating to the welfare of student trainees are not taken care of before embarking on the exercise, and in-terms of alternative places been sought for interns when their supposed first choice fail is non- existent and in a case where attempts are made it comes at a later date.

On matters relating to challenges, the results demonstrates that all the challenges listed by the researchers were the realities on the ground, and even identified poor attitude of industry towards the programme; suspicion of students by industry based workers, lot of time spent in finding placement, poor supervision from industry based supervisors, non-access to machinery and equipment, high cost in undertaking the programme, lack of training materials, lack of appropriate skills, tasks and job relating to programme of study, lack financial support and ability to secure placement close to placing of living. Carlson (2002) had earlier pointed out these as challenges students face whilst on industrial training spelling out competition for attachment places from other institutions, rough and tough environment for interns and sometimes gender disparities. Olugbenga (2009) believes aside these some interns also face financial problems. On another count, he recounted that, if effective and efficient training to is be realised and the needed skills created, institutions earmarked for internship training may have to acquire modern technology

On the issue of strategies, respondents agreed entirely with all the strategies outlined by the study for enhancing the attachment programme. Meanwhile the students were quick to point out that supervision should be prompt on the part of institutional based supervisors, whiles encouraging industry based supervisors to step up in their duties in-terms of assessment. Kemp and Foster (1995) indicated a solid partnership with industry will improve relationship. Beachle and Earle (2008) adding to it called on society to create desirable attitudes and relevant skills as they are the end beneficiaries of the students after graduation, and hence, the need for collaboration by stakeholders to enhance the programme. Arikewuyo (1996) sees the programme as, "a cannot do without exercise", advocating for students to be placed under competent, specialized supervisors who are experienced and seasoned to achieve the needed impact.

Takoradi Polytechnic is a government owned tertiary institution in Ghana, to be precise in the Western region. It is the oldest among the rest, and the premier polytechnic in Ghana. The institution since 1952 has endeared itself and always at the forefront of polytechnic education. Through research and practical based training has made its mark at both the national and international scene. Like its counterparts has a well- established and vibrant Industrial Liaison Office (ILO) solely charged with the responsibility of liaising between students, lecturers and industries to acquire the needed exposure in the related industries. Tsibuah (2013) discussing industrial training programme of Takoradi Polytechnic indicated it is mandatory for every student in the institution to proceed on industrial training before 
graduation. An implication that, their graduation is tied to the industrial training programme. He expatiated the programme is a core course, and every student is obliged to participate and pass before he/she can complete school. At Takoradi Polytechnic the programme is designed for both students and staff alike to acquire practical, managerial and hands on experience related to their area of study and teaching respectively.

The vision of Takoradi Polytechnic is to achieve excellence in manpower training and action research in order to provide support for industry and commerce in the field of manufacturing, commerce, science and technology, applied arts and science and to encourage study and research in technical subjects at the tertiary level (Takoradi Polytechnic Diary 2014). At Takoradi Polytechnic industrial training programme for students are fashioned into four; general attachment for first and second year higher national diploma students(HND), Competence-Based Training (CBT) programme for engineering students, the semester-out programme for fashion design and technology students and internship for second year Bachelor of Technology(B-Tech) students. As a way of assisting lecturers to acquaint themselves with current trends in their field in the industry, arrangements are made by the ILO for lecturers to also acquire practical skills and knowledge by getting attached to industries (Tsibuah, 2013). For the general industrial attachment programme, the duration is at least three months (12weeks); and that of the semester out-programme is four months (sixteen weeks).

\subsection{Problem Definition}

Graduate unemployment in Ghana is a worry to society, and a pain in the neck of successive governments, who have tried all sorts of tricks, tactics and implementation of special initiatives and programmes, but it's had little or no impact. Our higher educational institutions are also not helping matters as their focus is to churn out products who practically can do nothing, when they find themselves in industry, and only fit for white colour jobs. As a result polytechnics were made to structure their programmes such that it can produce well educated and skilled graduates to take up the challenge. In response to this, the polytechnics introduced industrial training programme with the aim of attaching students to course related industries to be exposed to the working environment, acquire practical skills and knowledge in their field of endeavours, get abreast of technological trends in the industry, and distinguish them from their university counterparts. There is also a wide gap between academia and industry as the collaboration or the intended partnership to be is non -existent, programmes offered by polytechnics is still seen as carbon copy of the universities, graphic art and engineering are learning with inadequate and obsolete equipment, technology and software programmes, with industry doing practically nothing about it, therefore raising concerns, arguments and counter arguments by society. Students also raise vital issues in connection with the industrial training which is becoming a yearly ritual with the individual ILOs looking on helplessly.

The background given is enough justification that the present study, is needed therefore, to identify and discuss some of the pertinent issues, which has become a yearly ritual, posing enormous challenges for student trainees and improve upon it. The aim of this paper is that it will identify and discuss the issues; its outcome will provide suggestions on ways to minimise and as well help students better prepare for their future career.

\subsection{Purpose of the Study}

The aim of the present study is to examine the industrial training programme of Takoradi Polytechnic. The following specific objectives will guide the study:

1. To examine the preparation of the industrial liaison office (ILO) before students embark on industrial training.

2. To identify and discuss the challenges and benefits of the industrial training programme.

3. To suggest ways of enhancing the programme

\subsection{Research Questions}

1. What activities does the ILO embark upon before students go on industrial training?

2. What challenges and benefits are associated with the industrial training?

3. How best can the programme be enhanced to improve the future career of students?

\section{Methodology}

\subsection{Research Design}

The study employed both the quantitative and qualitative research approaches. The justification for the choice is that both have their merits and demerits in research, and in a situation where both approaches are employed alongside, 
one takes care of the weakness of the other making the results very reliable. The qualitative method was used to explain the phenomenon as they exist in their natural setting and the quantitative was used to examine the frequencies and percentages to give meaning to figures. Data for the study was collected mainly from students and where there was the need for clarification fell on the ILO.

\subsection{Study Population and Sample}

The study population comprised students of Takoradi Polytechnic, and on a more specific note $2^{\text {nd }}$ and $3^{\text {rd }}$ year students of the four schools thus, Engineering, Applied Art and Science and Business. The rationale for employing only the two levels (2\&3) is that, they have embarked on the industrial training for two years, and stand to have more experience to respond to the issues at stake. A total of five hundred students from $2^{\text {nd }}$ and $3^{\text {rd }}$ year were surveyed

\subsection{Instrument Description}

The researchers developed an instrument tagged Industrial Training Programmes of Polytechnics Questionnaire (ITPPQ), which was used for the study. The self-administered questionnaire was developed with five sections. The section A, contained personal data of the respondents (demographic features, while the other four had items on the study variable. Section B, C, D and E had items centered on the ILO, students, challenges, benefits and the strategies of enhancing the training programme. The response format of ITPPQ is a four point rating scale: strongly agree (SA), agree (A), disagree (D), and strongly disagree (SD). The instrument was presented to two officials in the industrial liaison for face validity.

\section{Discussion and Analysis of Results}

\subsection{Demographic Features}

Table 1 exhibiting the demographic characteristics of respondents shows that male respondents outnumbered their female counterparts, an indication that male students enroll into our polytechnics more than their female compatriots. This could be attributed to the fact that polytechnics are carved to train personnel for middle level manpower supervisory role and per observation the position and its demand, has been found to be the preserve of men, possibly the trend. With respect to age a greater proportion of the respondents were within the range of $21-25$, thus $71 \%$, with 30 plus accounting for $42 \%$. The trend shows people who enroll into the polytechnic these days are very young compared to previous years, which implies the nation has a good and bright future as well as a strong human resource capacity base to sustain national development in the near future.

In terms of level of academic pursuit, it was a reflection of reality in that, first and second year students that proceeded on internship programme as stipulated by the polytechnics Act 2007(act 745), 1992, between them the study had 95\%. The figure for the final years could be due to the fact that, they had refers in the previous years, and had to embark on the exercise to redeem their image to merit graduation. Most of the respondents from the survey conducted were from the business school; somehow it's a true reflection of the situation on the ground, as they command the numbers in the polytechnic. On another platform, it could be that students from the other schools failed to submit their logs books at the point of collection early, as the questionnaires were administered at that point, but on the whole the figures shows students fail to submit their log books early indicating non adherence to rules and regulations governing internship exercise in the polytechnic. The study considering the sectors of internship placement for interns revealed that, a greater majority of the interns were placed or attached to private organisations thus $49.79 \%$, with $48.54 \%$, and $1.67 \%$ having the opportunity to serve with public and non-governmental organisations respectively. This implies gradually the pressure on public institutions is being eased, alongside the notion that graduates will only want to work in public firms after school. 
Table 1. Summary of Response on Demographic Characteristics of Respondents

\begin{tabular}{|c|c|c|c|}
\hline Characteristics & $\mathbf{N}$ & Frequency & Percent \\
\hline Gender & 480 & & \\
\hline Male & & 306 & 63.8 \\
\hline Female & & 174 & 36.2 \\
\hline Age & 480 & & \\
\hline $16-20$ & & 42 & 8.8 \\
\hline $21-25$ & & 340 & 70.8 \\
\hline $26-30$ & & 78 & 16.2 \\
\hline $30+$ & & 20 & 4.2 \\
\hline Level & 480 & & \\
\hline HND 1 & & 258 & 53.8 \\
\hline HND 2 & & 195 & 40.6 \\
\hline HND 3 & & 27 & 5.6 \\
\hline Schools & 480 & & \\
\hline Business & & 207 & 43.1 \\
\hline Applied Science & & 58 & 12.1 \\
\hline Engineering & & 124 & 25.8 \\
\hline Applied Arts & & 91 & 19.0 \\
\hline
\end{tabular}

Source: Field Survey, 2014

Table 2 exhibits the mean ratings and standard deviation of each item on the scale of evidence of early preparation for industrial training. The computed or calculated means shows that alternative placement is quickly organized for students when their first choice place fails (2.13), it was closely followed by the schooling of interns adequately on what is expected at each stage of writing the report (2.09) in the same vein departmental coordinators teach students how to write the report(2.04). On the other hand students welfare issues are discussed thoroughly, and taken care of by the ILO before they go on training(2.06), respondents professed being briefed as to what to expect before their departure and last but not least the ILO providing all the needed information and as well mentally, psychologically, and physically psyching students before the training programme.

Table 2. Evidence of Early Preparation

\begin{tabular}{|c|c|c|c|c|c|}
\hline Item & $\mathbf{N}$ & Min & Max & Mean & $\begin{array}{l}\text { Standard } \\
\text { Deviation }\end{array}$ \\
\hline Attachment letters/logbooks is issued out to students on time & 480 & 1 & 4 & 1.49 & 0.609 \\
\hline Attachment openings are made known to students earlier in the semester & 480 & 1 & 4 & 1.57 & 0.639 \\
\hline Orientation/workshops are organized on time for interns & 480 & 1 & 4 & 1.68 & 0.666 \\
\hline $\begin{array}{l}\text { Students welfare issues are discussed and taken care of by ILO before } \\
\text { they go on training }\end{array}$ & 480 & 1 & 4 & 2.06 & 0.822 \\
\hline $\begin{array}{l}\text { Alternative placement is quickly organized for students when their first } \\
\text { choice fail }\end{array}$ & 480 & 1 & 4 & 2.13 & 0.827 \\
\hline ILO provides the needed information to students prior to each training & 480 & 1 & 4 & 1.89 & 0.704 \\
\hline $\begin{array}{l}\text { Students are mentally, psychologically and physically psyched for the } \\
\text { programme }\end{array}$ & 480 & 1 & 4 & 1.89 & 1.162 \\
\hline $\begin{array}{l}\text { Departmental coordinators school interns on how to write industrial } \\
\text { training reports }\end{array}$ & 480 & 1 & 4 & 2.04 & 0.850 \\
\hline $\begin{array}{l}\text { Students are schooled adequately on what is expected of them in each } \\
\text { stage of writing the report }\end{array}$ & 480 & 1 & 4 & 2.09 & 0.814 \\
\hline Industry is briefed on what expect before students go on attachment & 480 & 1 & 4 & 2.00 & 0.816 \\
\hline Assumption of duty forms are given to interns early before vacation & 480 & 1 & 4 & 1.62 & 0.706 \\
\hline
\end{tabular}

Source: Field Survey, 2014 
This section of the survey conducted touched on the perceived challenges students face when they go on attachment. Table 3 presents the summary of the views of students on the matter. Respondents were asked to indicate whether they agree or disagree on the items presented. Out of the 27 items under consideration 5 of them stood tall amongst the rest. Thus the issue of sexual harassment, extortion and intimidation of students by workers led the ratings with a mean score of (2.97), closely on its heels is poor organisational supervision of trainee students (2.96). Negative supervisor attitude was also not tolerated by respondents with a mean score of (2.90). One surprising item was the fact that, school based supervisors asks interns to bring their log books for assessment, instead of going to the workplace (2.83); it implies supervisors do not go to do their work of which huge sums of money have been voted for. The last but not least item was industry's expectation of trainee students being unreasonable and lack of job description with mean scores of 2.77, 2.77 respectively.

Table 3. Summary Statistics of Challenges of Industrial Attachment

\begin{tabular}{|c|c|c|c|c|c|}
\hline Statement & $\mathbf{N}$ & Min & Max & Mean & Std Deviation \\
\hline There is a weak partnership between academia and industry & 480 & 1 & 4 & 2.46 & 0.922 \\
\hline There is a poor attitude of industry towards the programme & 480 & 1 & 4 & 2.67 & 0.889 \\
\hline Workers in industry feel threatened by the presence of interns & 480 & 1 & 4 & 2.75 & 0.848 \\
\hline Students spend a lot of time securing placement for the programme & 480 & 1 & 4 & 1.88 & 0.871 \\
\hline $\begin{array}{l}\text { Industry based supervisors connive with interns to adopt a lackadaisical } \\
\text { attitude towards the programme }\end{array}$ & 480 & 1 & 4 & 2.74 & 0.933 \\
\hline Students are not given access to machinery and equipment to try hands on. & 480 & 1 & 4 & 2.55 & 1.008 \\
\hline $\begin{array}{l}\text { Firms do not have space to accommodate trainees and resort to running shift } \\
\text { or reject them outright }\end{array}$ & 480 & 1 & 4 & 2.21 & 0.9661. \\
\hline $\begin{array}{l}\text { Industry based supervisors allow students to assess themselves due to lack } \\
\text { of understanding of issues }\end{array}$ & 480 & 1 & 4 & 2.49 & 0.941 \\
\hline $\begin{array}{l}\text { School based supervisors ask interns to bring their log books for assessment } \\
\text { instead of going to the work place }\end{array}$ & 480 & 1 & 4 & 2.83 & 1.062 \\
\hline Budget for industrial training is highly inadequate & 480 & 1 & 4 & 2.18 & 0.916 \\
\hline Lack of training materials in the firms & 480 & 1 & 4 & 2.55 & 0.987 \\
\hline Inadequate firms relating to students programme of study & 480 & 1 & 4 & 2.31 & 0.955 \\
\hline Difficulty in securing firms close to place of abode & 480 & 1 & 4 & 2.05 & 0.915 \\
\hline $\begin{array}{l}\text { Lack of financial support for interns on training(transport/food, medical } \\
\text { services, insurance, accommodation and stipends }\end{array}$ & 480 & 1 & 4 & 1.66 & 0.868 \\
\hline Sexual harassment, extortion and intimidation of students by industry & 480 & 1 & 4 & 2.97 & 1.033 \\
\hline $\begin{array}{l}\text { ILO encourages students to give feedback regarding organisations conduct } \\
\text { and the programme }\end{array}$ & 480 & 1 & 4 & 2.00 & 0.834 \\
\hline Grading system for assessment is ambiguous & 480 & 1 & 4 & 2.47 & 0.904 \\
\hline Organisation supervision is poor & 480 & 1 & 4 & 2.96 & 0.917 \\
\hline Negative supervisor attitude & 480 & 1 & 4 & 2.90 & 0.928 \\
\hline Lack of job description & 480 & 1 & 4 & 2.77 & 0.924 \\
\hline Trainees are made to do menial jobs & 480 & 1 & 4 & 2.49 & 1.040 \\
\hline Lack of responsibilities and limited opportunities & 480 & 1 & 4 & 2.55 & 0.970 \\
\hline Uncomfortable and hectic working environment & 480 & 1 & 4 & 2.60 & 0.962 \\
\hline Class of place of attachment & 480 & 1 & 4 & 2.43 & 0.888 \\
\hline High industrial expectation & 480 & 1 & 4 & 2.77 & 0.894 \\
\hline ILO handles students' complaints thoroughly. & 480 & 1 & 4 & 2.46 & 0.922 \\
\hline The duration for the industrial programme is highly inadequate & 480 & 1 & 4 & 2.47 & 0.988 \\
\hline $\begin{array}{l}\text { Industry based supervisors meet attachés periodically to answer questions, } \\
\text { guide performance and provide resources to facilitate the exercise }\end{array}$ & 480 & 1 & 4 & 1.97 & 0.963 \\
\hline
\end{tabular}


Table 4 reports the means and standard deviations of 9 supposed benefits derived by students who usually embark on industrial training programmes. Most of the respondents perceive that out of the 9 items listed; interns are exposed to machines and resources related to course of study but not available in schools (1.78), internship offers trainees the opportunity to put into practice the theory learnt in school(1.53), industrial training program pave way for trainees to learn techniques in solving real world of work related issues and contribute valuable ideas to national development(1.51), and internship keep trainees abreast of changing industrial culture and trends in technology, and industrial training programs increases students opportunity of getting employed with the following means respectively 1.65 and 1.47 . The expatiation implies that respondents confirmed the items given them, indicating they really benefit from industrial training programmes, with an average mean mark of 1.52 .

Table 4. Summary Statistics of Benefits Derived from Industrial Training Programme

\begin{tabular}{lccccc}
\hline Statement & N & Min & Max & Mean & Std. deviation \\
\hline $\begin{array}{l}\text { Internship offers the trainee the opportunity to put } \\
\text { into practice the theory learnt in school }\end{array}$ & 480 & 1 & 4 & 1.53 & 0.704 \\
$\begin{array}{l}\text { Interns are exposed to machines and resources } \\
\text { related to course but not available in institutions }\end{array}$ & 480 & 1 & 4 & 1.78 & 0.785 \\
$\begin{array}{l}\text { Trainee gain a lot of knowledge from industry } \\
\text { based supervisors, professional mentors and older } \\
\text { employees when they go on attachment }\end{array}$ & 480 & 1 & 4 & 1.46 & 0.601 \\
$\begin{array}{l}\text { Trainees build the spirit of teamwork and network } \\
\text { when they go on attachment }\end{array}$ & 480 & 1 & 4 & 1.44 & 0.589 \\
$\begin{array}{l}\text { Industrial attachment inculcates in trainees the } \\
\text { right attitude towards work(dressing, time to } \\
\text { report to work, effective communication skills and } \\
\text { mannerism }\end{array}$ & 480 & 1 & 4 & 1.42 & 0.579 \\
$\begin{array}{l}\text { Industrial training programmes pave the way for } \\
\text { trainees to learn techniques in solving real world } \\
\text { of work related issues and contributes valuable } \\
\text { ideas }\end{array}$ & 480 & 1 & 4 & 1.51 & 0.633 \\
$\begin{array}{l}\text { Industrial training is an avenue for trainees to } \\
\text { showcase their abilities and potential to industry } \\
\text { and government }\end{array}$ & 480 & 1 & 4 & 1.43 & 0.580 \\
$\begin{array}{l}\text { Industrial training programmes increases students } \\
\text { opportunity of getting employed }\end{array}$ & 480 & 1 & 4 & 1.47 & \\
$\begin{array}{l}\text { Internship keeps trainees abreast of changing } \\
\text { industry culture and trends in technology }\end{array}$ & 480 & 1 & 4 & 1.65 & 0.718 \\
\hline
\end{tabular}

Source: Field Survey, 2014

Table 5 touching on the effective ways to enhance the industrial programme of polytechnics in Ghana, reported the following means for the most tolerated and deemed effective items thrown to respondents during the survey. Respondents found the item; ILO should be able to find placement of students (1.67), industry based supervisors should be monitored and encouraged to work effectively, feedback from industry/firms should be made known and discussed with students and industry based supervisors be well oriented on how to train interns, all having a mean score of 1.61. Stakeholders meeting should be organized to know what industry expectation of interns before embarking on the programme. All respondents strongly agreed to the issues with a mean mark of 1.52 as well as minimum value of 1.42 and maximum value of 1.67 respectively. 
Table 5. Summary Statistics of Effective Strategies to Enhance Industrial Training

\begin{tabular}{|c|c|c|c|c|c|}
\hline Statement & $\mathbf{N}$ & Min & Max & Mean & Std. Deviation \\
\hline $\begin{array}{l}\text { Partnership and collaboration between industry and } \\
\text { academia must be strengthened very well }\end{array}$ & 480 & 1 & 4 & 1.45 & 0.561 \\
\hline $\begin{array}{l}\text { There should be an early follow up to find out that } \\
\text { students are at post whilst on training }\end{array}$ & 480 & 1 & 4 & 1.52 & 0.623 \\
\hline $\begin{array}{l}\text { Industry based supervisors should be monitored and } \\
\text { encouraged to work well. }\end{array}$ & 480 & 1 & 4 & 1.61 & 0.708 \\
\hline $\begin{array}{l}\text { Feedback from industry/firms should be made known and } \\
\text { discussed with students }\end{array}$ & 480 & 1 & 4 & 1.61 & 0.634 \\
\hline $\begin{array}{l}\text { A post attachment seminar should be organized for } \\
\text { stakeholders (industry, supervisors, academia) }\end{array}$ & 480 & 1 & 4 & 1.60 & 0.692 \\
\hline $\begin{array}{l}\text { Industry based supervisors should be well oriented on how } \\
\text { to train interns }\end{array}$ & 480 & 1 & 4 & 1.61 & 0.680 \\
\hline $\begin{array}{l}\text { There should an effective supervision of student trainees } \\
\text { from both institution and industry }\end{array}$ & 480 & 1 & 4 & 1.56 & 0.640 \\
\hline ILO should be able to find placement for students & 480 & 1 & 4 & 1.67 & 0.800 \\
\hline $\begin{array}{l}\text { A national advisory board should be set up to champion } \\
\text { the course of industrial training and canvas for funding }\end{array}$ & 480 & 1 & 4 & 1.55 & 0.651 \\
\hline $\begin{array}{l}\text { Industry should see students as potential assets and not } \\
\text { threats }\end{array}$ & 480 & 1 & 4 & 1.44 & 0.592 \\
\hline $\begin{array}{l}\text { Industry should pencil down outstanding students and } \\
\text { monitor their progress }\end{array}$ & 480 & 1 & 4 & 1.52 & 0.643 \\
\hline $\begin{array}{l}\text { A stakeholders' meeting could be organized to know what } \\
\text { industry expects from interns }\end{array}$ & 480 & 1 & 4 & 1.59 & 0.666 \\
\hline
\end{tabular}

Source: Field Survey, 2014

\subsection{Findings}

Per the data presentation and analysis, the following findings were extracted out of the study based on the thematic areas;

\subsubsection{Evidence of Early Preparation}

Based on the data presented on table 4.2 and its analysis, the survey revealed that alternative placement for attachment is quickly organized for students when their first choice places fail, students are schooled adequately on what is expected of at each stage of the report writing. In the same vein departmental representatives take them through the report writing. Industry is briefed on what to expect from interns, and last but no least the ILO provides the needed information to and prepare them mentally, psychologically and physically before they go on the training. These set of findings were consistent with the study by Derrick (1969) which sought to emphasise that student trainings should always be in the known as to the object of the training they embarking on. Truelove (1997) buttressing his point did indicate that being aware of the objective of the industrial training becomes motivational grounds for trainees, and confidence booster for the exercise. Meanwhile, student's welfare issues are discussed thoroughly and taken care of by the ILO before they go on training, this finding was contrary to Effah et al(2014) study which posited that students of Kumasi polytechnic welfare issues are not taken care of before they go on industrial training programme, then it implies the ILO is not doing its work well and may need to sit up.

\subsubsection{Challenges of Industrial Training}

Empirical evidence from table 4.3 indicates that all the 27 items of challenges outlined by the study to the respondents were the reality on the ground as the declaration was overwhelming from the mean scores. The respondents pointed out the following as the topmost of all; were sexual harassment, extortion and intimidation of students by workers; negative supervisor attitude, school based supervisors asking interns to bring their logbooks for assessment instead of going to the workplace; lack of job description; unreasonable expectation from students by 
industry, and industry based supervisors conniving with trainees to adopt a lackadaisical attitude towards the industrial programme. These challenges together with the others were consistent with what Carlson (2002) noted as challenges associated with industrial training programmes all over the world, citing competition among institutions for places, rough terrain for students especially females students in male dominated world.

\subsubsection{Benefits of Industrial Programme}

Empirical evidence from the results on table 4.4 demonstrated that all the benefits outlined to the respondents were real and exactly what they experienced when they go on training. The interpretation of the data gathered from the survey that the mean scores of the items were between the ranges of 1.42 to 1.78 , thus all respondents affirming their agreement with the issue. The perceived benefits pointed out by the respondents that they derive from industrial training programmes are;

The study discovered that the industrial training offers trainees' opportunity to put into practice the theory learnt in school, this earlier in literature had been pointed out by Fox (2001) and Neuman (1999) who disclosed industrial practical training is considered an opportunity to close gap between school learned theory and practical reality and what is taught in school.

Exposure to machines and resources related to course of study; knowledge acquisition from supervisors and mentors,

Development of teamwork spirit, network and learning of right attitude towards work, this particular finding was found to be related to Maher and Graves (2008) study touching on the importance of industrial training, that students who embark on industrial training or attachment develop much greater confidence, and always much at ease when absorbed into real working life situations

Learning of new techniques and solving of real world of work related issues, in relation to this finding, Ab Rahman, Omar, Kofli, Mat, Osman and Darus (2009) indicated the object of industrial training is to expose students' trainees to the whims and caprices of the working environment. In the same vein Shipton et al. (2006) in support of this argument also noted that industrial training helps graduates to manage what he termed as entry shock.

The study revealed that industrial training creates the platform for the showcase of ability and potential to government and industry. This finding in literature had earlier been noted by Highham and Seymore II (1996) for some students, it is required to be met in order to graduate, whiles others believe it is a platform to get connected, explore new fields, and acquire experience

Increase in the chance of employment and keeping interns abreast of technological trends in industry was consistent with findings in literature as discovered by Neuman (1999) and Cates-McIver (1999) industrial training is a golden opportunity to try, test before buying, students they might wish to recruit after graduation.

\subsubsection{Effective Strategies to Enhance the Programme}

It was discovered from table 4.5 that the respondents affirmed all the twelve(12) issues that were proposed by the study to enhance the industrial attachment programme of Takoradi polytechnic all the twelve (12) items outlined were unanimously agreed to by the respondents as being effective and formidable to improve the programme. The study advocated for a solid partnership and collaboration between industry and academia and its subsequent strengthening this outcome or finding is consistent with Kemp and foster (1995) assertion that industry has a relevant role to play to shape trainees to become a formidable workforce armed with all the knowledge and required skills to enter the world of work. In the same vein the results also shows there should be a follow up to ascertain whether interns are work or not whilst on training, while industrial based supervisors. Stakeholders meeting advocated to be held after each training period to evaluate the programme and industry's expectation of students for subsequent internships. Industry based supervisors should were charged to encourage and monitored, and be well oriented to make the exercise achieve its needs or objectives, these two had earlier been noted by Beachle and Earle(2008) who argued that effective and efficient attachment program should attain its set goals. They further added society will do as good by establishing the needed attitudes and skills as it is the end beneficiary of the students after school hence, the need for stakeholders meeting to digest and contribute to the improvement of the programme. Mention should also be made of the ILO making the effort to get placement for interns rather than, students searching for them. Per the findings it is believed that if the outlined strategies are adhered to strictly and implemented it is inevitable that the industrial training programme of Takoradi polytechnic will be a model for other tertiary institutions, and the aim of polytechnic education of producing middle level manpower will be achieved, and the blend of theory with practicals shall be the order of the day and the resultant effect national development growth. 


\section{Conclusion}

Industrial training has been seen by interns or students a very valuable learning process and experience for which they should receive academic credit, financial compensation and earn a grade for it, valuable than case teaching that formal training should be at the beginning of industrial trainings, to expose them to world of work, arm them with required skills and knowledge and the right mix of attitude to be able to fit into the job market immediately after school. Based on the key discoveries of the study it can be affirmed that; alternative placement for attachment is quickly organized for students when their first choice placement fails, students are taken through report writing, given the needed or requisite information by the ILO before they proceed on training and their welfare need are well taken care of ahead of the training. These indicators shows stringent efforts are made to prepare them early for the exercise. Notwithstanding, the training has never been free of challenges notably amongst them; sexual harassment, extortion and intimidation of trainees by workers, negative supervisor attitude and unreasonable expectations by firms amongst others. In spite of all these challenges the study can conclude that industrial training is not an optional enhancement to academic record but an essential experience and skill acquiring component in tertiary education.

\section{Recommendations}

A more strengthened partnership and cooperation between higher educational institutions (HEIs) is very vital and as much as possible be fostered and developed. This can be done by appointing senior practitioners as external assessors, an advisory board and visiting lecturers to enhance understanding between organisations and institutions.

Trainees should be encouraged to offer feedback regarding many aspects of the organisation and their training programmes as a whole and as well report indecent conduct industry to ILO.

ILO should endeavour to organize post- industrial training seminar seeking to bring together all the stakeholders (students, industry and institutions and practitioners) to evaluate periodically the programme and come out with the way forward to enhance the programme.

Industry should be well oriented and educated to fully to supervise, train and play their role in development of students

\section{References}

Ab Rahman, M.Z., Omar, M.Z., Kofli, N.T., Mat, K., Osman, S.A., \& M Darus, Z. (2009).Assessment of Engineering Students Perception after Industrial Training Placement. European Journal of Social Sciences, 8(3), 420-431.

Amaniampong K. (2014). Importance of Polytechnic Education and the Challenges it faces. Takoradi: Ghana.

Andreas Blom, H. S. (2011). Employability and Skill Set of Newly graduated Engineers in India. World Bank. http://dx.doi.org/10.1596/1813-9450-5640

Arikewuyo, M.O. (1999). Improving teachers' productivity in Nigeria, basics of education. Lagos: Triump Books Publishers.

Baechle, T. R., \& Earle, R. W. (2008). Essentials of Strength Training and Conditioning. European Journal of Innovation Management, 6(1), 41-52.

Bennett, R. (2002). Employer's Demands for Personal Transferable Skills in Graduates: A Content Analysis of 1000 Job Advertisements and an Associated Empirical Study. Journal of Vocational Education and Training, 54(4), 457-75. http://dx.doi.org/10.1080/13636820200200209

Blom, A., \& Saeke H. (2011). Employability and Skill of Set of Newly Graduated Engineers in India. Policy Research Working Paper 5640. The World Bank-South Asia Region Education Team, pp.2-60.

Carlson, A. C. (2002). The benefits of Work-integrated Learning, ITE Teachers' Conference, Malaysia.

Cates-Mc Iver, L. (1999). Internships and Co-op programs, A Valuable Combination for Colleges. Black Collegian, 30,84 .

Collins, A.B. (2002). Gateway to the Real World, Industrial Training: Dilemmas and Problems. Journal of Tourism Management, 23(2002), 93-96. http://dx.doi.org/10.1016/S0261-5177(01)00058-9

Cox, S., \& King, D. (2006). Skill Sets: An Approach to Embed Employability in Course Design. Education and 
Training, 48(4), 262-74. http://dx.doi.org/10.1108/00400910610671933

Dagyenga, M. (2013). Time to Make our Polytechnics Purely Technological Institutes. Retrieved November 4, 2013 from http://www.modernghana.com/news/478399/1/time-to-make-ourpolytechnics-purelytechnological.html

Derrick, T. (1969). The effect of industrial training on engineering undergraduates. Education and Research, 70(12), 67-69. http://dx.doi.org/10.1080/0013188690120112

Effah, B., Boampong, E., Adu, G., Anokye, R., \& Asamoah, J.N. (2014). Issues of the Industrial Training Programme of Polytechnics in Ghana: The Case of Kumasi Polytechnic. Journal of Education and Practice, $5(5), 39-46$.

Emeka, E. O. (2011). Youth Unemployment and Implication for Stability Democracy in Nigeria. Journal of Sustainable Development in Africa, 13(1), 358-373.

Ghana MOESS (Ministry of Education Science and Sports) (2008). Preliminary Education Sector Performance Report (ESPR), Accra, Ghana.

GNA (2013). Minister of Education Expresses Concern about Graduate Unemployment. Retrieved December 15, 2013

from http://www.modernghana.com/news/462985/1/minister-of-education-expressesconcern-aboutgrad.html

GNA (2012). GEA Initiates moves to Formulate Policy on Attachment. Retrieved September 20, 2013 from http://www.modernghana.com/news/390037/1/gea-initiates-moves-to-formulate-policy-onattachm.html

Harvey, L. (2004). On Employability. The Higher Education Academy. Retrieved from http://www.Palatine.ac.uk/files/emp/1236.pdf

Jamali, D. (2005). Changing Management Paradigms: Implications for Educational Institutions. Journal of Management Development, 24(2), 104-115. http://dx.doi.org/10.1108/02621710510579473

Kagaari, J.R.K. (2007). Evaluation of the Effects of Vocational Choice and Practical Training on Students' Employability. Journal of European Industrial Training, 31(6), 449-471. http://dx.doi.org/10.1108/03090590710772640

Kemp, I., \& Foster, K. (1995). From ivory towers to factory floors. Education +Training, 37(2), 26-32. http://dx.doi.org/10.1108/00400919510084531

Maher, A., \& Graves, S. (2008). Graduate Employability: can higher education deliver? Treshold Press Ltd: Newbury Berks, UK.

Miner. J.B., \& Crane, D.P. (1995). Human Resource Management. New York: Harper Collins.

Ministry of Education. (1993). The Polytechnic Law 1992, PNDC Law 321, Accra, Ghana.

Neuman, H. (1999). Internship. Journal of Career World, 27(6), 16.

Nevett, T. (1986). Internship Problems are not Entrance in the United States. Journal Marketing Educator, 5(3), 3.

Olugbenga, A. F. (2009). Towards effective SIWES curriculum development in applied sciences for adequate skills utilization: A Case study of the school of applied science, Nuhu Bamali Polytechnic, Zaria. Pacific Journal of Science and Technology, 10(1), 234-239.

Pianko, O. (1996). Poor Internships. Management Review, 85(12), 31-33.

Seymore II, D., \& Higham, M.T. (1996). The Access Guide to International Affairs Internships. Washington, D.C: Access.

Sheldon, P., \& Thornwaite, L. (2005). Employability Skills and Vocational Education and Training Policy in Australia: An Analysis of Employer Association Agendas. Asia-Pacific Journal of Human Resources, 43(3), 404-425. http://dx.doi.org/10.1177/1038411105059100

Shipton, H., West, M., Birdi, K., \& Patterson, M. (2006). HRM as a Predictor of Innovation. Human Resource Journal, 16(1), 3-27. http://dx.doi.org/10.1111/j.1748-8583.2006.00002.x

Truelove, S. (1997). Training in Practice. Maldon: Blackwell Publishers.

Yusof, N.A., Fauzi, S.N.F., Abidin, N.Z., \& Awary, H. (2013). Improving Graduates Employability Skills through Industrial Training: Suggestions from Employers. Journal of Education and Practice, 4(4), 23-28. 